\title{
REALIZING LEGAL PROTECTION FOR OUTSOURCING WORKERS THROUGH EMPLOYMENT SETTING SYNCHRONIZATION ${ }^{\Omega}$
}

\author{
Khairani \\ Law Faculty of Andalas University Padang \\ E-mail: khairani.lubis6@gmail.com
}

\begin{abstract}
Debating on the outsourcing existence in Law No.13 of 2003 regarding to Labor, is still continuing even though there has been a decision of Indonesia Constitutional Court (MK) who stated the rules that the content of Article 65 paragraph (7) and Article 66 paragraph (2) has been outlawed. The problems of this research are: How is the outsourcing concept of regulating in the labor law and the regulation of the labor minister No. 19 of 2012; and What effort to keep the outsourcing arrangement can provide legal protection for workers? This research use juridical normative method. The research finds that some of the concept is in contradiction with the 1945 constitution and another Law which is related to the protection of labor, and even with the other articles that exists in the Labor Law itself so thats the norm contains contradictio adconceptio. Therefore, the system of outsourcing that will be regulated should consider the principles of goof outsourcing governance. They are: legal protection, non-discrimination, worker as the subject not as an object, benefit and welfare, sustainable working relation, and the shifting of protection to the labor.
\end{abstract}

Keywords: law protection, outsourcing setting, synchronization

\begin{abstract}
Abstrak
Perdebatan mengenai keberadaan outsourcing di dalam UU Ketenagakerjaan masih berlang-sung meski sudah ada Putusan Mahkamah Konstitusi yang menyatakan bahwa ketentuan Pasal 65 (7) dan 66 (2) tidak berlaku lagi. Permasalahan dalam penelitian ini adalah Bagaimanakah konsep/rumusan outsourcing dalam UU Ketenagakerjaan dan Peraturan Menteri Tenaga Kerja No. 19 Tahun 2012, dan Apakah upaya yang dilakukan agar pengaturan outsourcing bisa memberikan perlindungan hukum bagi pekerja? Penelitian ini menggunakan metode yuridis normatif. Hasil penelitian menunjukkan bahwa be-berapa rumusannya bertentangan dengan UUD 1945 dan UU lainnya yang berkaitan dengan perlindungan kepada pekerja, bahkan dengan pasal-pasal yang terdapat pada UU Ketenagakerjaan itu sendiri sehingga normanya mengandung kontradiksi antar konsep (contradictio adconceptio). Agar pengaturan outsourcing dapat menjamin perlindungan hukum perlu dilakukan revisi terhadap ketentuan Pasal 6566. Revisi harus memperhatikan prinsip-prinsip good outsourcing governance, yakni: perlindungan hukum, nondiskriminasi, pekerja harus dianggap sebagai subjek bukan objek dalam hubungan kerja, benefit and welfare dari pekerja, hubungan kerja yang berkesinambungan, pengalihan perlindungan terhadap pekerja.
\end{abstract}

Kata kunci: perlindungan hukum, pengaturan outsourcing, sinkronisasi.

\section{Introduction}

The genesis of Law No. 13 Year 2003 on Employment (hereinafter referred to as Law of Employment) brought fundamental changes in Indonesia's industrial relations because of a rule intended to regulate the relations between workers/employees and employers as a whole also re-

$\Omega$ Doctoral Research Grant with Contract Number Contract No.:04/H.16/DD/LPPM/2015 gulate matters related to labor and employers well before, during and after their employment.

This law also regulates the material related to the outsourcing which basically is a novelty in the field of labor in Indonesia, as contained in article 64-66 of Employment Law, altough there is only three chapters but it has had enormous influence on the development of labor in Indonesia. In other side, it is very detrimental to the workers, because the settings are complica- 
ted and have various interpretations from the norm so it can not protect the rights of workers. The formulation of outsourcing has always been a matter demanded by laborers/workers in many demonstrations in order to be eliminated from the Employment Law. The demands even comes until making a petition to the Constitutional Court (hereinafter referred to as MK) 2 times that begged to be tested against the provisions of $\mathrm{Ar}$ ticle 64-66 (about outsourcing). Since its incompatible with the principles contained in Article 27 and Article 28 28D (1) and (2) of 1945 Constitution which provides protection to get a job for every citizen. The second decision of the Court states that there are two phrases in articles 65 and 66 of labor Law which is no longer valid. ${ }^{1}$

One purpose or goal of the Employment Law establishment is to provide protection to the parties in the industrial side i.e. workers and employers. However, with the outsourcing arrangement actually emasculate the rights that should be accepted by the workers. Castration on workers' rights precisely because of the lack of clarity about the concept of outsourcing arrange-ments ${ }^{2}$ as contained in the General Conditions and in Article 64 to Article 66 of the Labor Law. The establishment of an Act should be beneficial to all parties as mentioned by Jeremy Bentham ${ }^{3}$ about how is law become more functional and give happiness to many people as a respect to workers and employers, the laws that protect humans as they work and assured their results. ${ }^{4}$

The fundamental problems of outsourcing can be viewed at: first, the word 'outsourcing' is not found in the Employment Law, in the Act, it is some work deliver to give an interpretation in the implementation. Second, on the concept of employment relationship, the rules cause the haziness as mentioned in Article 65 which states that the work can be done from a direct or indirect orders of the employer company. This things shows a question; that the direct orders are to the employment contractor or the worker? Then the provisions of Article 66 which requires the work relationship between the employee and service provider of workers even when the jobs is on the employer company. ${ }^{5}$ Contract Agreement of work is outsourced job where the main Contractor handed/contracting outside work to another company, namely the sub-contractor, and then the sub contractor hiring workers/employees to carry it out with its own management, workers are working for a company that received a contract of work, in other words there is a working relationship. While on the second outsourcing which is the Services Company workers handed workers to another company, namely the company Employers (enterprise users) ${ }^{6}$ and then give a job to that employee in the company under the supervision. Third, the provisions concerning the form of agreements with the outsourcing that allow Certain Time Work Agreement (PKWT) or Employment Agreement indefinite time (PKWTT). Means that there is no allowed firmness forms of work.

\section{Problems}

Based on the description of the background above, the problems can be formulated in this study, i.e. How does the concept/formulation of outsourcing in the Employment Law and the Regulation of the Manpower Minister No. 19 of 2012 and what efforts to keep the outsourcing arrangement can provide legal pro-tection for workers?

\section{Reseach Method}

4 Jeremy Bentham, 1979, Teori Perundang-undangan: Prinsip-prinsip Legislasi, Hukum Perdata dan Hukum Pidana, translated from The Theory of legislation, by N.M Tripathi Private Limited, Bombay, translated by Nurhadi, Bandung: Nusa Media dan Nuansa, page 130.

5 Aloysius Uwiyono, "Reformasi di Bidang Ketenagakerjaan”, Jurnal Legislasi Indonesia, Vol. 8 No.3, September 2011, Jakarta: Direktoran Jendral Peraturan Perundangundangan Kementerian Hukum dan Hak Asasi Manusia RI, page 391-393.

6 Ibid, page 393 
This Research is the study of law, therefore, the approach used is normative juridical and historical approach. The data used in this study is only of secondary data, the collection of legal materials are done through the library research which is obtained through conventional search and electronic technology (Internet sites).

\section{Discussion}

The concept of Outsourcing formulation in the Employment and Permanker No. 19 of 2012 Act

The presence of Employment Law is expected to answer the needs of industral people, in fact the government found the difficulty in creating an accommodative Employment Law which can be accepted by all stakeholders involved especially the workers and employers in the process of forming the employment regulation, so that A. Uwiyono ${ }^{7}$ termed it as Employment Law at a crossroads because it regulates the two different interests even clashed with each other, so that all the entry into force of approximately 12 years basically can not be effective because there is always a demand from the workers to have the particular matter of the labor Law was abolished, for example about outsourcing, even the enactment rejection of this Act also comes from the employers who are consider that the arrangements about severance pay are way too burdensome to employers. ${ }^{8}$

The outsourcing formulation which has only three chapters contained in Article 64-66 of the Manpower Act contains some unclear norms, give a different interpretations in its implementtation. This can be seen as follows: first, the use of the term. The provisions of Article 64 is mentioned only as the handed of some job to other companies through chartering agreements and

7 Aloysius. Uwiyono, "Implikasi Hukum Pasar Bebas dalam Kerangka AFTA Terhadap Hukum Ketenagakerjaan di Indonesia”, Jurnal Hukum Bisnis, Vol. 22, Jan-Feb 2003", Jakarta: Yayasan Pengembangan Hukum Bisnis.

8 Budi Santoso, “Justifikasi Efisiensi Sebagai Alasan Pemutusan Hubungan Kerja”, Jurnal Mimbar Hukum, Vol. 25, No. 3, October 2013, Yogyakarta: Law Faculty of Gadjah Mada University, page 407.

9 Khairani, "Analisis terhadap outsourcing ditinjau dari konsep Hukum dan Pelaksanaannya", Jurnal Kanun, 2012, Banda Aceh: Law Faculty of Syiah Kuala University Banda Aceh, page 57

10 M. Fauzi, "Aspek Hukum Penyerahan Sebagian Pelaksana an employee providers treaties, ${ }^{9}$ the term of outsourcing can not found by a single word. This is interpreted as the outsourcing in a daily life. The Outsourcing was originally a term in the business world to meet the workforce needs of an enterprise to bring in from outside the company. ${ }^{10}$.

Based on Article 64 of the Labor Law, there are two forms of outsourcing Labor Agreement which is "Works Employment Agreement" and the "Employment Agreement Provision of Services Labour or Workers". The first outsourcing is about the job, legal construction is the main contractor who made a contractor's job on the subcontractor. To do the work which is given by main contractor, sub contractor requires a worker ${ }^{11}$ or in the other word according to Kamal Hasan Hali$\mathrm{li}$, there are two kinds of outsourcing namely the first, outsourcing business and second, outsourcing labor. ${ }^{12}$ That's where the sub-contractor hiring workers to do the job given by the main contractor. So there is a working relationship between the sub-contractor and workers.

Second, the job that could be submitted to another company. According to Article 65 it has been confirmed that the work which can be outsourced is the supporting job, not the main job of the company, while according to Permenker No.19 of 2012 jobs that will be submitted to the contractor company is determined by the Entrepreneurs/business Association sectors that are known by the Ministry of Labor. Based on this provision, the material contained in Permenker is wider than the contents of the Employment Law.

Third, The Forms of the Employment. The provisions of Article 65 paragraph (6), (7) and Article 66 paragraph (2) on b that the employment relationship in the implementation of work refer-

an Pekerjaan Kepada Perusahaan Lain (outsourcing)", Ju rnal Risalah Hukum, Vol. 2, No. 2, 2012, Samarinda: La w Faculty of Mulawarman University, page 89.

11 Aloysius Uwiyono, "Ketidakpastian Hukum Pengaturan Outsourcing dalam Undang-undang Nomor 13 Tahun 2003", Jurnal Legislasi Indonesia, Vol. 8 No. 3, September 2011, Jakarta: Direktorat Jenderal Peraturan Perundang-undangan Kementerian Hukum dan Hak Asasi Manusia RI, page 392.

12 Kamal Halili Hasan, "Outsourcing and Its Effect On Employees: New Malaysian Law", Industrial Law Journal Article (ILJA), Vol. 3, 2013, Graduate, Selangor: Faculty of Law Universiti Kebangsaan Malaysia. 
red to in paragraph (1) stipulated in a written employment agreement between other companies and the employed workers/laborers, it can reffered to the employment agreement for an unspecified time or a certain time work agreement if it meets the requirements referred to in Article 59. The workers who will be employed by the contractor companies should have to be tied into a written employment agreement such in the PKWTT or PKWT. If made with the agreement, it must be fulfilled as the requirements contained in Article 59 of the Employment Law. Implementation of these agreement provisions entered into by employers more tends to wear PKWT although the work is permanent and constantly exist in the company. Constitutional Court Decision No.27PUU-IX/2011 has declared this provision is no longer valid because it is contrary to Article 27 paragraph (2) and Article 59 of the Manpower Act, but it turns out in the Ministrial Regulation No.19 of 2012 on Job Submission to the Company by the Treaty Works and Services Delivery Workers still provide opportunities for entrepreneurs to conduct labor relations through PKWT as contained in Article 15 and Article 19.

First, the concept of employment relationship. The provisions of Article 66 paragraph (2a) provides that there are an employment relationship between worker/labor and service provider company. The purpose of this statement also calls for the employment relationship between service providers and workers who will be working on the company's employers by written relationship. The concept of the employment relationship contained in Article 1 point 15 of The working relationship is the relationship between employers and workers/laborers by employment agreements, which have an element of workers, wages, and commands.

Based on the provisions of Article 65 paragraph (6) and (7), employment agreement can happen as a manifestation of an employment relationship, because the employer had handed over the work to be completed by the contractor work to provide their own workers that will carry out the work in completing as expected by employer. This means that jobs are the ones holding contractors working relationship with the work- ers and meet the elements of employment agreements as referred to in Article 1 paragraph 15 that fulfilled the command element, wages and no job. So there will be a clear working relationship in the employment contract of agree-ment between the contractor jobs with workers.

Its different with the legal relationship between the outsourced workers with the provision of worker agreements. Employment Law requires an employment relationship between the service providers working with outsourced workers, but the work that will be done by the worker is at the employer company. If it is associated with the concept of labor contract law as the basis of the employment relationship in accordance with the provisions of Article 1 point 15 , the working relationship between the service providers with outsourced workers are not met element is that there are jobs, there are command and wages. The service providers have only arbitrary orders and pay the wages while the employment is on the employer (in place of the employer). So that the legal relationship in the agreement work services provider is bias and unclear. This ambiguity will affect the accountability towards all the consequences that will occur to workers, for example if there is any conflict or adverse action between workers and employers should be their responsibility but in Article 66 the responsibility of the service provider.

Employment relationship of the employment agreement contract of work can be illustrated as:

A

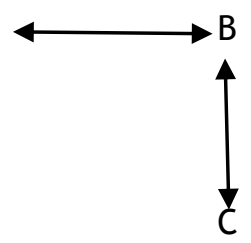

$A=$ Employer

$\mathrm{B}=$ Job Contractor

$\mathrm{C}=$ Worker

Description: $A$ give jobs to $B$ to be solved by a cooperation. $B$ finish the work from $A$ by holding a working agreement with $C$ as someone who will carry out the work. B become a fully responsible one for the implementation of work and carry out the orders and paying wages to $C$ as workers. There is a real working relationship between $B$ to 
C. While the working relationship with the treaty provision of worker is:

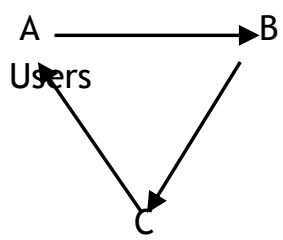

$$
\begin{aligned}
& A=\text { Employers }=\text { Service } \\
& B=\text { Service Providers } \\
& C=\text { Worker }
\end{aligned}
$$

Description: $A$ is a users work/service provider requires workers to carry out the work, $B$ is provide the workers. $A$ and $B$ have the cooperation agreements. $C$ was employed in A. C is working on $\mathrm{A}$ as a service user. The employment agreement work services provider is more suitable of workers called as the agreement of work placement.

\section{The Effort to Make Outsourcing Rule can Pro- vide Legal Protection for Workers}

In order to achieve legal protection for the parties, especially the workers, then it should be revision of the outsourcing arrangement contained in Article 64-66 with attention to other regulations also concerning the relationship between workers and employers. In other words, as a country which adheres to the principle of legality if legal protection is not in accordance with the legislation, the service provider can not be prosecuted because of regulations or laws that specifically say so. To realize the legal protecttion to outsourced workers should be a change/ revision or even delete the provisions of Article 65 and Article 66 of the Labor Law. If the revision is done then the legal concept should be made clear and definite by using the logic of the law that can protect both parties involved in the employment agreement. It is clear who is the subject and what is the object contained in the employment agreement.

Things that need to be done in accordance with the formulation of the concept of the problems that have been described above, are: first, in the General Provisions precisely in Article 1 shall be confirmed regarding the terminology does it mean to work Chartering Agreements and treaties service providers so that the material contained in Article 64 immediately understood and there is no longer a different interpretation in the community. Second, the Permenakertrans norm that need to be harmonized with Article 65 paragraph (2) the labor law is Article 3 (2) governing the types of work that may be submitted to another company. Article 65 paragraph (2) of the Act Employment is supporting activities of the company as a whole, meaning that these activities are activities that support and facilitate the implementation of the main activities. In Permenaker as the implementing regulations of Article 65 of the Labor Law jobs may be submitted to the company contractor assigned by the association of business sector established under the legislation as specified in Article 4 paragraph (1) Permenakertrans which states that the Association business sector as referred to in Article 3 paragraph (2) $c$ should make the process of implementation of the work flow of activities in accordance sectors respectively. This means that the authority to determine the flow of activities submitted to the employer company will be used as the basis for the company employers in the delivery part of its work through a contract of work. Under these provisions are in the authority of the employer so feared jobs created by entrepreneurs are subjective so that work should not be allowed to be outsourced. The authority should have been carried out by an independent body or tripartite institutions in employment so that the flow of activities that draw core support activities and activities made more objective.

Third, then need to be removed provisions of Articles 15 and 19 Permenaker because the material they provide an opportunity to the employer to make arrangements with PKWT, whereas the existing Constitutional Court Decision No. 27/PUU-IX/2011, which states that the employment relationship should not be based on PKWT if work not in accordance with Article 59 of the Employment Law. Fourth, For the Agreement service providers, especially Article 29, which includes "In terms of labor relations based on agreements specified time object work remains" to be revised sound that still allow the agreement with PKWT for work that is fixed, it should be emphasized should not be made an 
agreement with PKWT if the work performed is constantly exist or remain.

Fifth, It should be clearly defined concept of employment relationship between employers and employees, because the formula contained in the provisions of Article 66 paragraph (2a) this may lead to uncertainty in the relationship between employer and employee, or the relationship between the employee and the company work services. Each can be throwing responsibility for the protection of workers. When examined in the agreement provision of worker employment relationship is actually between the workers and the company the employer (user service workers) rather than by service providers, because that gives jobs, orders and wages are corporate users work services instead of companies that provide workers for instance, work may be handed over to another company is cleaning service, security guards, drivers who are employed by the service provider to the enterprise user. So there are discrepancies between Article 1 point 15 to Article 66 paragraph (2) letter a. If this is allowed the discrepancies can cause uncertainty for employers and workers. Therefore, should the employment relationship in outsourcing agreements should be clear to the workers who do the work relationship so that it can refer to the provisions of $\mathrm{Ar}$ ticle 1 point 15 of the Manpower Act so that workers are protected. The provisions in this article should be changed to make a clear formulation of what the responsibility of the employer/employee service user and what the responsibility of the service provider the rights of workers in the outsourced workers, for example regarding overtime, giving treatment if sick, wages, transport. In addition it should also be improved concept of the dispute settlement mechanism in case of disputes between employers and employees and a dispute between an employer and a company service providers. Thus there is no transfer of responsibility for

13 Asriwijayanti, "Perlindungan Hukum bagi pekerja di Perusahaan Swasta", Jurnal Perspektif Hukum, Vol. 2 No. 2, 2003, Surabaya: Law Faculty of Hang Tuah University Surabaya, page 12 .

14 Asriwijayanti, "Perlindungan Hukum Bagi pekerja yang di PHK karena melakukan Pelanggaran", Jurnal Dinamika Hukum, Th. X No. 21, 2004, Purwokerto: Faculty of Law, Jenderal Soedirman University, page 109. workers in the employment relationship agreement provision

As a result, there are many workers' rights are harmed by employers, it is not surprising to know that there are many of them declare that the protection of workers was minimal, even though it is set in such a way in the legislation with a good concept, but in practically it is still lacking, as is often the case in the employment relationship such as the lack of protection for contract workers because there is almost never registered to the Department of labor, the reason lies in the termination of employment ${ }^{13}$, there is no restriction of norms violation ${ }^{14}$. In terms of layoffs for workers committing a major offense is still an alternative that should be cumulative ${ }^{15}$. The Misinterpretation of severance pay on termination is because a change ${ }^{16}$. Moreover, the way providing protection to workers is expressly provided by law, submitted to the company service providers. The implementation of synchronization rules on outsourcing is expected to create laws to ensure legal certainty for workers so as to provide better protection to the parties in the employment relationship.

\section{Conclusion}

Based on the discussion, it can be concluded that: first, the outsourcing arrangement contained in Article 64-66 of the Manpower Act contains various weaknesses and vagueness of the concept so that there is a contradiction between the concepts to provide a protection to the worker become more difficult. Contradiction concept of Article 65-66 to Article 27 paragraph (2) and Article $28 \mathrm{D}$ of the 1945 Constitution as well as Article 59 of the Employment Law, the Ministerial Regulation No.19 of 2012 on the delivery of some of the work to other companies. Second, Revise the contrary articles, still consider the synchronization between basic regulations and implementing regulations, which is Article 65 and 66 should be in line with article 27,

15 Asriwijayanti "Perlindungan Hukum Bagi pekerja yang di PHK karena melakukan kesalahan Berat", Jurnal Legality, Vol. 13 No. 1, 2005, Malang: Law Faculty of Muhammadiyah Malang University, page 108.

16 Asriwijayanti "Perlindungan hukum bagi pekerja yang di PHK karena adanya Perubahan di Perusahaan", Jurnal Dialektika, Vol. 4 No. 1, 2005, Jakarta: Islamic State University Jakarta, page 73. 
paragraph 2, Article 28D of the 1945 Constitution and Constitutional Court Decision No.27/2011, as well as Permenaker should be in line with labor laws, Article 27 paragraph (2), 28D of the 1945 Constitution and Constitutional Court Decision No. $27 / 2011$.

\section{Recomendation}

According to the authors, there should be a comprehensive revision of the Employment Law Article 64-66 with still looking into the good outsourcing governance principles, which are: first, the protection of law; secondly, non-discrimination; third, the employee shall be considered as a subject not an object in the employment relationship; fourth, benefit and welfare of workers, fifth, continuous working relationship; sixth, diverse protection of workers. It is expected to materialize legal pro-tection for workers.

\section{References}

Ali, Ahmad 2002. Menguak Tabir Hukum: Suatu Kajian Filosofis dan Sosiologis. Jakarta: Toko Gunung Agung Tbk.

Asmirawati, Nova. "Pekerja Outsourcing dalam Undang-undang Ketenagakerjaan". Jurnal Legislasi Indonesia. Vol. 8 No. 3. September 2011. Jakarta: Direktorat Jenderal Peraturan Perundang-undangan Kementerian Hukum dan HAM RI;

Asriwijayanti. "Perlindungan Hukum bagi Pekerja di Perusahaan Swasta". Jurnal Perspektif Hukum. Vol. 2 No. 2. 2003. Surabaya: Law Faculty of Hang Tuah University;

"Perlindungan Hukum Bagi pekerja yang di PHK karena Melakukan Kesalahan Berat”. Jurnal Legality. Vol. 13 No. 12005. Malang: Law Faculty of Muhammadiyah University;

. "Perlindungan hukum bagi pekerja yang di PHK karena adanya Perubahan di Perusahaan". Jurnal Dialektika. Vol. 4 No.1 2005. Jakarta: Islamic State University;.

. "Perlindungan Hukum Bagi pekerja yang di PHK karena melakukan Pelanggaran". Jurnal Dinamika Hukum. Th. X No. 21 2004. Purwokerto: Law Faculty of Jenderal Soedirman University;

Baxi, Upendra. on Preface of The Theory of Legislation. Bandung: Nusa Media dan Nuansa;
Bentham, Jeremy. 1979. Teori Perundang-undangan: Prinsip-prinsip Legislasi. Hukum Perdata dan Hukum Pidana. Bandung: Nusa Media dan Nuansa;

Fauzi, M. “Aspek Hukum Penyerahan Sebagian Pelaksanaan Pekerjaan Kepada Perusahaan Lain (outsourcing)". Jurnal Risalah Hukum. Vol. 2 No. 2. 2012. Samarinda: Law Faculty of Mulawarman University;

Hasan, Kamal Halili. "Outsourcing And Its Effect On Employees: New Malaysian Law". Industrial Law Journal Article (ILJA). Vol. 3 2013. Graduate. Selangor: Faculty of Law Universiti Kebangsaan Malaysia;

Khairani. "Analisis terhadap outsourcing ditinjau dari konsep Hukum dan Pelaksanaannya". Jurnal Kanun. 2012. Banda Aceh: Law Faculty of Syiah Kuala University;

"Kedudukan Outsourcing Pasca Putusan Mahkamah Konstitusi Nomor 27/PUU-IX/ 2011". Jurnal Konstitusi. Vol. 11 No. 4 December 2014. Jakarta: Kepaniteraan and Sekretariat Jendral MK RI;

Santoso, Budi. "Justifikasi Efisiensi sebagai Alasan Pemutusan Hubungan Kerja”. Jurnal Mimbar Hukum. Vol. 25 No. 3, October 2013. Yogyakarta: Law Faculty of Gadjah Mada University;

Uwiyono, Aloysius. "Reformasi di Bidang Ketenagakerjaan". Jurnal Legislasi Indonesia. Vol. 8 No. 3 September 2011. Jakarta: Direktorat Jendral Peraturan Perundangundangan Kementerian Hukum dan Hak Asasi Manusia Rl;

. "Implikasi Hukum Pasar Bebas dalam Kerangka AFTA Terhadap Hukum Ketenagakerjaan di Indonesia". Jurnal Hukum Bisnis. Vol. 22. Jan-Feb 2003. Jakarta: Yayasan Pengembangan Hukum Bisnis;

-.--.-. "Ketidakpastian Hukum Pengaturan Outsourcing dalam Undang-undang Nomor 13 Tahun 2003". Jurnal Legislasi Indonesia. Vol. 8 No.3- September 2011. Jakarta: Direktorat Jendral Peraturan Perundangundangan Kementerian Hukum dan Hak Asasi Manusia RI;

. "Ketidakpastian Hukum Pengaturan Outsourcing dalam Undang-undang Nomor 13 Tahun 2003". Jurnal Legislasi Indonesia. Vol. 8 No. 3. September 2011. Jakarta: Direktorat Jendral Peraturan Perundang-undangan Kementerian Hukum dan Hak Asasi Manusia RI. 